\title{
ANALISIS EMOSIONAL, KEBIJAKSANAAN PEMBELIAN DANPERHATIAN SETELAH TRANSAKSI TERHADAP PEMBENTUKAN DISONANSI KOGNITIF KONSUMEN PEMILIK SEPEDA MOTOR HONDA PADA UD. DIKA JAYA MOTOR LAMONGAN
}

\author{
*( Edie Sugiarto \\ Prodi Manajemen, Fakultas Ekonomi, Universitas Islam Lamongan \\ Jl. Veteran No.53A Lamongan \\ Telp. ( 0322 ) 324706, Faks. ( 0322 ) 324706 \\ Email :jpim.unisla@gmail.com
}

\begin{abstract}
ABSTRAK
Penelitian ini merupakan jenis penelitian deskriptif kuantitatif dengan judul" analisa emosional, kebijaksanaan pembelian dan perhatian setelah transaksi terhadap pembentukan disonansi kognitif konsumen pemilik sepeda motor honda pada ud. dika jaya motor" .Tujuan penelitian ini adalah untuk mengetahui dan menganalisa faktor dimensi Emosional, Kebijaksanaan Pembelian dan Perhatian Setelah Transaksi mempengaruhi pembentukan disonansi kognitif konsumen pemilik sepeda motor Honda pada UD. Dika Jaya Motor Lamongan. Hasil uji Secara parsial diperoleh variabel bebas Emosional, Kebijaksanaan pembelian dan Perhatian setelah transaksi berpengaruh signifikan terhadap Pembentukan Disonansi Kognitif Konsumen pemilik sepeda motor Honda pada UD. Dika Jaya Motor Lamongan. Serta dari hasil uji F diperoleh Emosional, Kebijaksanaan pembelian dan Perhatian setelah transaksi berpengaruh signifikan terhadap Pembentukan Disonansi Kognitif $(Y)$ Konsumen pemilik sepeda motor Honda pada UD. Dika Jaya Motor Lamongan dan variabel yang paling dominan dalam mempengaruhi pembentukan disonansi kognitif adalah perhatian setelah transaksi.
\end{abstract}

Kata kunci : Emosional, kebijaksanaan pembelian, perhatian setelah transaksi

\section{PENDAHULUAN}

Pada umumnya masyarakat membeli motor untuk menikmati dua fungsi yaitu: bisa cepat sampai tujuan dan irit bahan bakar. Namun ditengah perkembangan dan juga persaingannya tersebut, industri otomotif ditanah air dihadapkan pada suatu dilema yang cukup komleks, yakni naiknya harga bahan bakar minyak (BBM) yang menjadi kebutuhan utama industri tersebut sehingga sangat mempengaruhi daya beli konsumen dan perilaku konsumen. Dengan adanya informasi baik positif maupun negatif yang berkembang di kalangan konsumen pemilik sepeda motor Honda, hal inilah yang membuat konsumen merasa dihadapkan pada suatu kondisi yang membingungkan, dimana kepercayaan mereka tidak sejalan bersama. Seorang konsumen dapat merasakan ketidaknyamanan setelah 
melakukan suatu pembelian atau tidak. Apabila konsumen merasakan ketidaknyamanan paska melakukan transaksi pembelian berarti konsumen telah mengalami disonansi kognitif.

Emosional adalah ketidak nyamanan psikologis yang dialami seseorang terhadap keputusan pembelian, dalam hal kondisi psikologi konsumen secara alami mempertanyakan apakah tindakan yang dilakukannya telah tepat. Perasaan tidak enak ini menyebabkan pembelian yang telah dilakukan menimbulkan disonansi pada diri konsumen. Rahayu (dalam Nasution, 2008:21) menyatakan bahwa Emosi dapat berfungsi untuk mengaktifkan dan mengarahkan perilaku. Emosi juga dapat menyertai perilaku itu sendiri, merupakan sumber kesenangan dan juga tujuan, emosi banyak berkaitan dengan upaya pencapaian tujuan yang di hambat sehingga memunculkan emosi marah, putus asa, atau bila suatu tujuan tercapai sehingga merasa senang, gembira, puas dan sebagainya.

Kebijaksanaan pembelian adalah Ketidaknyamanan yang dialami seseorang setelah transaksi pembelian dimana apakah sangat membutuhkan produk tersebut atau apakah mereka telah memilih produk yang sesuai. Dimensi ini menggambarkan bahwa pengakuan seseorang setelah melakukan pembelian yang menjadikan konsumen tersebut memiliki keraguan karena produk yang dibelinya kurang dibutuhkan atau kurang selektif dalam melakukan pembelian dengan apa yang dibutuhkan.

Perhatian setelah transaksi adalah ketidaknyamanan yang dialami seseorang setelah transaksi pembelian dimana mereka bertanya-tanya apakah mereka telah di pengaruhi oleh tenaga penjual yang bertentangan dengan kemauan atau kepercayaan mereka. Hal ini berkaitan dengan kekecewaan konsumen dimana pada kondisi ini konsumen cenderung kurang yakin dengan keputusan yang telah dibuatnya. Dimensi ini seperti perasaan adanya unsur penipuan serta perhatian konsumen pada transaksi pembelian produk yang telah dilakukan apakah terdapat kesalahan dalam memutuskan pembelian produk. Selain itu dimensi ini adalah perhaian konsumen pada transaksi pembelian produk yang telah dilakukan apakah pihak tenaga penjual telah memperpanjang hubungan dengan konsumen (relation marketing). Perumusan masalah penelitian ini sebagai berikut : 1.Apakah faktor Dimensi Emosional, Kebijaksanaan Pembelian dan Perhatian setelah transaksi berpengaruh secara parsial terhadap pembentukan Disonansi Kognitif? 2.Apakah faktor Dimensi Emosional, Kebijaksanaan Pembelian dan Perhatian setelah transaksi berpengaruh secara simultan terhadap pembentukan Disonansi Kognitif? 3.Dari ketiga faktor (Dimensi Emosional, Kebijaksanaan Pembelian dan Perhatian setelah transaksi) aspek manakah yang paling dominan dalam 
mempengaruhi

pembentukan

Disonansi Kognitif?

Menurut East (dalam Japarianto, 2006:83) Cognitive Dissonance dideskripsikan suatu kondisi yang membingungkan, yang terjadi pada seseorang ketika kepercayaan mereka tidak sejalan bersama. Kondisi ini mendorong mereka untuk merubah pikiran, perasaan dan tindakan mereka agar sesuai dengan pembaharuan. Disonansi dirasakan setelah seseorang berkomitmen pada dirinya sendiri dalam melakukan tindakan yang tidak kosisten dengan perilaku dan kepercayaan mereka yang lainnya.

Cognitive Dissonance terjadi bila informasi atau stimulus yang diterima oleh konsumen berbeda dengan apa yang sudah disimpan dalam memorinya sehingga tidak terjadi asosiasi positif. Pemasar sering menggunakan kiat cognitif dissonance ini untuk membuat konsumen berganti merek, dari merek kompetitor ke merek mereka. Menurut prasetijo (2005:123) Cognitive Dissonance Theory, teori ini ketidak nyamanan atau Dissonance terjadi apabila seorang konsumen memperoleh informasi baru yang bertentangan dengan apa yang diyakini atau sikapnya yang terdahulu.

Tujuan penelitian ini adalah untuk mengetahui dan menganalisa faktor dimensi Emosional, Kebijaksanaan Pembelian dan Perhatian Setelah Transaksi mempengaruhi pembentukan disonansi kognitif konsumen pemilik sepeda motor Honda pada UD. Dika Jaya Motor Lamongan.

\section{LANDASAN TEORI}

Sehubungan dengan permasalahan yang terdapat dalam penelitian ini maka diperlukan adanya teori-teori atau konsep-konsep yang memerlukan penjelasan. Dalam benyak perusahaan dewasa ini, pemasaran memegang peranan sebagai suatu faktor penting untuk tetap bertahan menjalankan usaha dan bergelut dalam dunia persaingan. Pemasaran merupakan factor vital sebagai strategi pesrusahaan dalam menjalankan usahanya, yang terutama berhubungan dengan konsumen. Kata pemasaran sendiri berasal dari kata pasar, atau bisa juga diartikan dengan mekanisme yang mempertemukan permintaan dan penawaran. Menurut Kotler ( 2002 : 9 ) "Pemasaran adalah proses social yang didalamnyaa individu dan kelompok mendapatkan apa yang meraka butuhkan dan inginkan dengan menciptakan, menawarkan, dan secara bebas mempertukarkan produks yang bernilai dengan pihak lain.

Faktor-faktor Yang Mempengaruhi keputusan Pembelian Konsumen

Menurut Kotler ( 2002 : 183 ) Faktorfaktor yang mempengaruhi keputusan pembelian konsumen yaitu :

a.Faktor Kebudayaan

Kebudayaan mempunyai penaruh paling luas dan mendalam terhadap prilaku konsumen. Terdiri dari budaya, sub budaya, dan kelas social. Budaya yang merupakan karakter paling penting dari suatu social yang membedakannya dari kelompok budaya lain menjadi penentu dan 
keinginan dan prilaku yang paling mendasar. Masing-masing budaya terdiri dari sub budaya yang memberikan lebih banyak ciri-ciri dan sosialisasi.Sub budaya adalah suatu kelompok homogeny atas sejumlah orang yang terbagi menjadi beberapa bagian dari keseluruhan suatu budaya. Masyarakat dalam suatu budaya dan sub budaya sesungguhnya terbagi dalam strata atau kelas social. Kelas social merupakan sekelompok orang yang sama-sama mempertimbangkan secara dekat persamaan diantara mereka sendiri.

b.Faktor Sosial

Pada umumnya konsumen sering meminta pendapat dari orang sekitas dan lingkungannya tentang produk apa yang harus dibeli. Karena itulah lingkungan sosial memberikan pengaruh terhadap prilaku konsumen. Faktor Sosial terdiri dari 3 bagian, yaitu : kelompok acuan, keluarga, dan peran. Kelompok acuan adalah semua kelompok yang memilki pengaruh langsung terhadap sikap / prilaku seseorang. Dengan pendapat yang diperoleh dari suatu kelompok maka konsumen dapat membuat keputusan konsumsi. Keluarga sebagai organisasi pembelian konsumen yang paling penting juga berpengaruh secara langsung terhadap keputusan seseorang dalam membeli barang sehari-hari. Sedangkan peran meliputi kegiatan yang diharapkan akan dilakukan seseorang. Suatu produk atau merk dapat menggambarkan peran dan status pamakainya.
c.Faktor Pribadi

Mulai dari bayi hingga dewasa dan menjadi tua, manusia selalu membutuhkan barang dan jasa. Pilihan barang yang dibeli secara otomatis dipengaruhi oleh keadaan ekonomi dan gaya hidup yang bersangkutan. Gaya hidup adalah cara hidup seseorang yang terlihat melalui aktivitas sehari-hari, minat dan pendapat seseorang. Seseorang dengan pendapatan yang tinggi dan gaya hidup mewah tentunya akan menentukan pilihan pada barang dan jasa yang berkualitas. Selain itu kepribadian dan konsep diri juga mempengaruhi pilihan produk. Konsep diri adalah bagaimana konsumen mempresepsikan diri mereka sendiri, yang meliputi sikap, persepsi, keyakinan, dan evaluasi diri. Karena sangat berguna dalam menganalisis prilaku sonsumen sehingga banyak perusahaan menggunakan konsep yang berhubungan dengan kepribadian seseorang.

\section{d.Faktor Psikologis}

Sikap pembelian psikologis dipengaruhi oleh empat facktor psikologis utama, yaitu : motivasi, persepsi, pembelajaran dan kepercayaan. Motivasi merupakan kebutuhan yang mendorong seseorang dalam melakukan sesuatu sesuai dengan tujuan yang ingin dicapai. Melalui motivasi proses pengamatan dan belajar seseorang memperoleh kepercayaan terhadap suatu produk yang secara otomatis mempengaruhi prilaku pembelian konsumen. Para konsumen mengembangkan beberapa 
kenyakinan mengenai ciri-ciri dari suatu produk dan selanjutnya akan membentuk suatu sikap konsumen terhadap produk tersebut.

\section{METODE PENELITIAN}

Jenis penelitian ini yang di gunakan oleh penulis adalah deskriptif kuantitatif. Sugiyono (2014:23) Data Kuantitatif adalah data penelitian yang berbentuk angka, atau data kualitatif yang di angkakan (skoring). di mana data dikumpulkan, dicatat, disusun dan disajikan dalam bentuk tabel frekuensi yang selanjutnya dilakukan pengukuran nilai-nilai statistiknya untuk membuktikan kebenaran terhadap teori.

"Populasi adalah wilayah generalisasi yang terdiri atas; obyek/subyek yang mempunyai kuantitas dan karakteristik tertentu yang ditetapkan oleh penulis untuk di pelajari dan kemudian ditarik kesimpulannya" (Sugiyono, 2014:61). Populasi pada penelitian ini sebanyak 100 responden dari seluruh konsumen pemilik sepeda motor Honda yang melakukan pembelian pada bulan Januari - Mei 2015 di UD. Dika Jaya Motor Lamongan.

Sampel adalah bagian dari jumlah karakteristik yang dimiliki oleh populasi tersebut Sugiyono (2014:62).Adapun yang menjadi sampel pada penelitian ini adalah sebanyak 50 sampel respoden dari konsumen pemilik sepeda motor Honda yang melakukan transaksi pembelian di UD. Dika Jaya Motor Lamongan.
Tenik penarikan sampel yang digunakan dalam penelitian ini adalah pengambilan sampel non-probabilitas. Adapun yang menjadi sampel dalam penelitian ini adalah setiap pembeli yang melakukan trasaksi pembelian sepeda motor Honda pada bulan Januari - Mei 2015 akan diberikan 1 (satu) suara, meskipun ia membeli lebih dari 1 (satu) sepeda motor Honda pada kurun waktu tersebut dan sepda motor Honda yang di beli digunakan sebagai kendaraan pribadi, dinas atau niaga.

Definisi Operasional Variabel adalah seperangkat petunjuk yang lengkap tentang apa yang harus diamati dan mengukur suatu variabel atau konsep untukmenguji kesempurnaan. Definisi operasional variabel ditemukan item-item yang dituangkan dalam instrumen penelitian ( Sugiyono, 2014:3 ).

Data yang dipergunakan dalam penelitian ini ada dua macam, yaitu data primer dan data sekunder:

\section{a. Data Primer}

Supriyanto dan Ernawati (2010 : 387), Data Primer ialah data yang dikumpulkan pertama kali. Dimana data tersebut diperoleh secara langsung dari obyek penelitian. Data primer dalam penelitian ini diperoleh dari hasil penyebaran kuesioner kepada para pembeli sepeda motor honda di UD. Dika Jaya Motor Lamongan.

b. Data Sekunder

Supriyanto dan Ernawati (2010 : 388), Data Sekunder ialah data yang dikumpulkan lebih dulu dengan tujuan dapat digunakan oleh orang lain. Data 
sekunder dalam penelitian ini diperoleh dari data yang bersumber dari UD. Dika Jaya Motor Lamongan dan sumber-sumber lain yang telah tersedia sebelumnya berkaitan dengan penelitian.

Dalam penelitian ini teknik pengumpulan data yang digunakan pada penelitian ini adalah :

\section{Observasi}

Sugiyono (2012:145) observasi adalah teknik pengumpulan data yang mempunyai ciri spesifik bila dibandingkan dengan teknik lain, yaitu wawancara dan kuesioner. Kalau wawancara dan kuesioner selalu berkomunikasi dengan orang, maka observasi tidak terbatas pada orang, tetapi juga obyek-obyek alam yang lain. Adapun observasi dalam penelitian ini dilakukan pada konsumen pemilik sepeda motor Honda di UD. Dika Jaya Motor Lamongan.

\section{Wawancara (Interview)}

Narbuko dan Achmadi (2010:83), wawancara adalah proses tanya-jawab dalam penelitian yang berlangsung secara lisan dalam mana dua orang atau lebih bertatap muka mendengarkan secara langsung informasi-informasi atau keteranganketerangan.

Dalam penelitian ini penulis melakukan wawancara dengan konsumen pemilik sepeda motor Honda pada bulan Januari - Mei 2015 di UD. Dika Jaya Motor Lamongan.

3. Dokumentasi

Arikunto (2010 : 274), Dokumentasi adalah pengumpulan data dengan mencari data mengenai hal-hal atau variabel yang berupa catatan, transkrip, buku, surat kabar, majalah, prasasti, notulen rapat, lengger, agenda, dan sebagainya.

\section{Kuesioner (Angket)}

Sugiyono (2012:142) Kuesioner merupakan teknik pengumpulan data yang dilakukan dengan cara memberi seperangka tpertanyaan atau pertanyaan tertulis kepada responden untuk dijawabnya.

Adapun responden adalah konsumen pemilik sepeda motor Honda pada UD. Dika Jaya Motor Lamongan yang diminta untuk memberikan jawaban atas pertanyaan yang terkait dengan Disonansi Kognitif dan faktor-faktor pembentukannya.

5. Studi Kepustakaan

Teknik studi kepustakaan adalah suatu metode pengumpulan data dengan cara mempelajari data-data yang diperoleh dari kepustakaan dan sumber-sumber lain yang dianggap dapat memberikan informasi yang relevan mengenai disonansi kognitif.

Sesuai dengan permasalahan yang ada, maka dalam penelitian ini variabel yang terdiri dari :

Variabel bebas/ Independent Variabel (X), Adapun yang menjadi variabel bebas (X) dalam penelitian ini adalah:

a. Dimensi Emosional $\left(\mathrm{X}_{1}\right)$ Indikatornya yaitu:

1) Merasa marah.

2) Merasakankecewa dengan diri sendiri.

3) Merasakantelah membuat sesuatu yang salah. 
b. Dimensi Kebijaksanaan Pembelian $\left(\mathrm{X}_{2}\right)$ Indikatornya yaitu :

1) Merasa telah membuat pilihan yang tidak tepat.

2) Merasa seharusnya tidak perlu membeli sepeda motor Honda.

3) Merasa Telah melakukan hal yang tidak tepat untuk membeli sepeda motor Honda.

c. Dimensi Perhatian Setelah

Transaksi $\left(\mathrm{X}_{3}\right)$

Indikatornya yaitu :

1) Merasa Telah melakukan suatu kesalahan dengan persetujuan yang telah dibuat.

2) Merasa telah melakukan suatu kebodohan.

3) Merasa tenaga penjual telah mengakibatkan kebingungan.

Variabel Terikat IDependen

Variabel(Y)

Indikatornya yaitu :

1) Merasa ingin berubah pikiran.

2) Merasa ingin berganti ke merek lain.

3) Merasa puas dan senang.

Analisis data adalah mengelompokkan data berdasarkan variabel dan jenis responden, mentabulasi data berdasarkan variabel dari seluruh responden, menyajikan data dari tiap variabel yang diteliti, melakukan penghitungan untuk menjawab rumusan masalah, dan melakukan perhitungan untuk menguji hipotesis yang telah diajukan (Sugiyono,2014:4).

Setelah data-data terkumpul, maka langkah selanjutnya adalah menganalisis data-data tersebut sehingga mempunyai makna untuk mengungkap berbagai masalah yang ada, khususnya pada dimensi emosional, kebijakan pembelian dan perhatian setelah transaksi terhadap pembentukan disonansi kognitif konsumen sepeda motor hondapada UD.Dika Jaya Motor Lamongan.

Tujuan dari analisis ini adalah untuk mengetahui besarnya pengaruh masing-masing variabel bebas terhadap variabel terikatnya, adapun rumus yang digunakan adalah sebagai berikut :

Uji Validitas

Validitas merupakan derajat ketepatan antara data yang sesungguhnya terjadi pada obyek penelitian dengan data yang dilaporkan oleh peneliti. Dengan demikian data yang valid adalah data "yang tidak berbeda" antara data yang dilaporkan oleh peneliti dengan data yang sesungguhnya terjadi pada obyek penelitian (Sugiyono, 2012:267). Untuk menguji validitas instrument menggunakan rumus product moment, Sugiyono (2014:352):

$r_{\mathrm{xy}}=\frac{n\left(\sum X Y\right)-\left(\sum X\right)\left(\sum Y\right)}{\sqrt{\left\{n \sum X^{2}-\left(\sum X\right)^{2}\right\}\left\{n \sum Y^{2}-\left(\sum Y\right)^{2}\right\}}}$

Keterangan:

$\mathrm{r}_{\mathrm{xy}}=$ validitas item yang dicari

$\mathrm{n}=$ Jumlah sampel/ responden

$\mathrm{X}=$ Skor responden untuk tiap item

$\mathrm{Y}=$ Total skor tiap responden

$\Sigma \mathrm{X}=$ Jumlah skor dalam distribusi $\mathrm{X}$

$\Sigma \mathrm{Y}=$ Jumlah skor dalam distribusi $\mathrm{Y}$

$\Sigma \mathrm{X}_{2}=$ Jumlah skor masing-masing skor $\mathrm{X}$

$\Sigma Y_{2}=$ Jumlah skor masing-masing skor $\mathrm{Y}$ 
Syarat minimun untuk dianggap memenuhi syarat validitas adalah kalau $r=0,6$. Jadi kalau korelasi antar butir dengan skor total kurang dari 0,6 maka butir dalam instrumen tersebut dinyatakan tidak valid.

\section{Uji Reliabilitas}

Uji reliabilitas merupakan derajad konsistensi dan stabilitas data atau temuan. Data dinyatakan reliabel apabila dua atau lebih peneliti dalam obyek yang sama menghasilkan data yang sama, atau peneliti yang sama dalam waktu berbeda menghasilkan data yang sama atau sekelompok data bila di pecah menjadi dua menunjukkan data yang tidak berbeda (Sugiyono,2011:268).

$$
\mathrm{r}_{11}=\frac{\mathrm{k}}{(\mathrm{k}-1)}\left\{1-\frac{\sum \alpha_{\mathrm{b}}^{2}}{\alpha_{\mathrm{i}}^{2}}\right\}
$$

Keterangan:

$\mathrm{r}_{11} \quad=$ Realibilitas instrumen

$\mathrm{k}=$ Banyaknya butir pertanyaan atau banyaknya soal

$$
\begin{array}{ll}
\alpha_{\mathrm{b}}^{2} & =\text { Jumlah butir varian } \\
\alpha_{\mathrm{i}}^{2} & =\text { Varian total }
\end{array}
$$

Syarat minimun untuk dianggap memenuhi syarat reliabilitas adalah kalau $r=0,6$. Jadi kalau korelasi antar butir dengan skor total kurang dari 0,6 maka butir dalam instrumen tersebut dinyatakan tidak reliabel.

1. Analisis Regresi Linier Berganda

Sesuai dengan tujuan penelitian dan rumusan hipotesis, maka teknik analisis data yang digunakan dalam penelitian ini adalah analisi sregresi linier berganda. Menurut Sugiono (2014:275). Adapun model persamaan regresinya sebagai berikut:

$$
Y=a+b_{1} X_{1}+b_{2} X_{2}+b 3 X 3
$$

Keterangan:

$\mathrm{Y}=$ Disonansi kognitif

$\mathrm{a}, \mathrm{b}=$ Koefisien regresi

$\mathrm{X}_{1}=$ dimensi emosional

$\mathrm{X}_{2}=$ dimensi kebijaksanaan pembelian

$\mathrm{X} 3=$ dimensi perhatian setelah transaksi

2. Analisis Korelasi

Arikunto (2010:313) Koefisien Korelasi adalah alat statistic, yang dapat digunakan untuk membandingkan hasil pengukuran dua variabel yang berbeda agar dapat menentukan tingkat hubungan antara variabel - variabel ini.

$r=\frac{n\left(\sum X Y\right)-\left(\sum X\right)\left(\sum Y\right)}{\sqrt{\left\{n \sum X^{2}-\left(\sum X\right)^{2}\right\}\left\{n \sum Y^{2}-\left(\sum Y\right)^{2}\right\}}}$

Dimana:

$\mathrm{r} \quad=$ Koefisien korelasi

$\mathrm{n}=$ Jumlah sampel/ responden

$\mathrm{X}=$ Variabel bebas

$\mathrm{Y} \quad=$ Variabel terikat

Tabel 1.

Interprestasi koefisien korelasi

\begin{tabular}{|c|c|}
\hline Interval koefisien & Tingkat Hubungan \\
\hline $0,00-0,199$ & Sangat Rendah \\
\hline $0,20-0,399$ & Rendah \\
\hline $0,40-0,599$ & Sedang \\
\hline $0,60-0,799$ & Kuat \\
\hline $0,80-1,000$ & Sangat Kuat \\
\hline
\end{tabular}

Sumber: Sugiyono (2011:184)

\section{Koefisien Determinasi $\left(\mathrm{R}^{2}\right)$}

Koefisien determinasi merupakan ukuran - ukuran untuk mengetahui 
kesesuaian atau ketepatan antara nilai dengan garis regresi dengan data sampel. Menurut Andi Supangat (dalam Sari, 2014:35). dapat dirumuskan sebagai berikut:

$\mathrm{Kd}=r^{2} \times 100 \%$

Sumber: Sugiyono (2008:257)

Dimana :

$\mathrm{Kd} \quad=$ Koefisien Determinasi

$\mathrm{r}=$ Koefisien Korelasi

4. Uji t ( Parsial )

Digunakan untuk mengetahui variabel-variabel bebas mana yang paling dominan berpengaruh terhadap variabel terkait, dengan rumus :

$$
\mathrm{t}=\frac{r \sqrt{n-2}}{\sqrt{1-r^{2}}}
$$

Sumber : Sugiyono (2014: 251)

Keterangan :

$t=$ Nilai hitung

$r=$ Koefisien korelasi

$n=$ Jumlah sampel

$\mathrm{r}^{2}=$ Standar error

1) HO : $b_{1}=b_{2}=0$ (tidak ada pengaruh yang nyata antara variable bebas terhadap variable terikat)

Hi : $b_{1} \neq b_{2} \neq 0$ (ada pengaruh yang nyata antara variable bebas terhadap variable terkait.

2) Tingkat signifikasi $(\alpha)$ yang digunakan $0,5 \%=0,05$

3) Kriteria yang dipakai dalam Uji t adalah :

a) Apabila $t_{\text {hitung }}>t_{\text {tabel }}$ atau $t_{\text {hitung }}<t_{\text {tabel }}$ maka H0 ditolak danHi diterima, berarti hipotesis diterima b) Apabila $t_{\text {hitung }}<t_{\text {tabel }}$ maka $\mathrm{H} 0$ diterima dan $\mathrm{Hi}$ ditolak, berarti hipotesis ditolak.

5. Uji F (Simultan)

Digunakan untuk mengukur tingkat signifikan berpengaruh antara variabel bebas (X) secara simultan terhadap variabel terikat $(\mathrm{Y})$ dengan rumus :

$$
\mathrm{F} \text { hitung }=\frac{\frac{R^{2}}{k}}{\frac{1-R^{2}}{n-k-1}}
$$

Sumber : Sugiyono (2014:235)

Keterangan :

$\mathrm{F}_{\text {hit }}=\mathrm{F}$ hasil perhitungan

$\mathrm{R}=$ Koefisien korelasi berganda

$\mathrm{K}=$ Jumlah variabel bebas independen

$\mathrm{n}$ = Jumlah sample

Untuk pengujian hipotesis pengaruh simultan variabel $\mathrm{X}_{1}, \mathrm{X}_{2}, \mathrm{X}_{3}$ terhadap (Y) digunakan Uji $\mathrm{F}$ dengan prosedur sbagai berikut :

$\mathrm{H} 0=\mathrm{b}_{1}=\mathrm{b}_{2}=0$ ( tidak ada pengaruh terhadap variabel terikat )

$\mathrm{Hi}=\mathrm{b}_{1} \neq \mathrm{b}_{2} \neq 0$ (ada pengaruh terhadap variabel terikat)

\section{HASIL PENELITIAN DAN PEMBAHASAN}

\section{Uji Validitas}

Uji validitas digunakan untuk mengukur sah atau tidaknya suatu kuesioner. Uji signifikansi dilakukan dengan membandingkan nilair ${ }_{\text {hitung }}$ dengan $r_{\text {tabel}}$. Pengujian validitas menggunakan product moment dengan melihat nilai sig $=5 \%$. Butiran pertanyaan dikatakan valid, jika skor item berkolerasi secara signifikan 
dengan total skor yang ditunjukkan dari nilair ${ }_{\text {hitung }}>\mathrm{r}_{\text {tabel }}$.

Uji validitas dalam penelitian ini di lakukan dengan menggunakan komputer program SPSS 17 for Windows, adapun hasil perhitungan pada tabel berikut ini:

Tabel 2.

Hasil Uji Validitas

\begin{tabular}{|c|c|c|c|c|}
\hline $\begin{array}{c}\text { Vari } \\
\text { abel }\end{array}$ & $\begin{array}{c}\text { Per } \\
\text { tan } \\
\text { ya } \\
\text { an }\end{array}$ & $\mathrm{r}_{\text {hitung }}$ & $\mathrm{r}_{\text {tabel }}$ & $\begin{array}{c}\text { Keteran } \\
\text { gan }\end{array}$ \\
\hline \multirow{3}{*}{$\left(\mathrm{X}_{1}\right)$} & 1 & 0,717 & 0,278 & Valid \\
\cline { 2 - 5 } & 2 & 0,430 & 0,278 & Valid \\
\cline { 2 - 5 } & 3 & 0,436 & 0,278 & Valid \\
\hline $\left.\mathrm{X}_{2}\right)$ & 1 & 0,493 & 0,278 & Valid \\
\cline { 2 - 5 } & 2 & 0,288 & 0,278 & Valid \\
\cline { 2 - 5 } & 3 & 0,694 & 0,278 & Valid \\
\hline \multirow{3}{*}{$\left(\mathrm{X}_{3}\right)$} & 1 & 0,797 & 0,278 & Valid \\
\cline { 2 - 5 } & 2 & 0,392 & 0,278 & Valid \\
\cline { 2 - 5 } & 3 & 0,441 & 0,278 & Valid \\
\hline$(\mathrm{Y})$ & 1 & 0,572 & 0,278 & Valid \\
\cline { 2 - 5 } & 2 & 0,735 & 0,278 & Valid \\
\cline { 2 - 5 } & 3 & 0,303 & 0,278 & Valid \\
\hline
\end{tabular}

Sumber: lampiran 2

Tabel 2 menunjukkan bahwa semua indikator yang digunakan untuk mengukur variabel - variabel yang digunakan dalam penelitian ini mempunyai koefisien korelasi lebih besar dari $r_{\text {tabel }}(0,278)$. Artinya semua indicator sebagai pengukur dari masing - masing variable tersebut adalah valid.

1. Uji Reliabilitas

Uji reliabilitas bertujuan untuk menunjukkan sejauh mana alat ukur yang digunakan cukup akurat, stabil atau konsisten.Uji reliabilitas dikatakan reliable jika nilai reliabilitas $>0,6$. Uji validitas dalam penelitian ini di lakukan dengan menggunakan komputer program SPSS 12 for Windows, adapun hasil perhitungan pada tabel berikut ini:

Hasil pengujian reliabelitas dengan SPSS metode Alpha Cronbach's diperoleh koefisien Alpha pada semua variable bebas Emosional sebesar 0,621, Kebijaksanaan pembelian sebesar 0,615, Perhatian setelah transaksi sebesar 0,635 dan variable terikat Disonansi Kognitif sebesar 0,649 lebih besar dari standart reliabilitas $(0,6)$ dengan tingkat signifikasi $\alpha=5 \%$ sehingga dapat disimpulkan bahwa instrument dalam variable bebas dan terikat adalah Reliabel.

2. Regresi Linier Berganda

Analisis regresi linier berganda digunakan untuk mengasumsikan bahwa terdapat hubungan linier antara variable Disonansi kognitif dengan variable Emosional, Kebijaksanaan pembelian dan perhatian setelah transaksi terhadap Disonansi kognitif. Berdasarkan hasil perhitungan regresi perhitungan regresi pada tabel diatas didapatkan suatu persamaan regresi sebagai berikut:

$\mathrm{Y}=0,884+0,185 X_{1}+0,254 X_{2}+$ $0,281 X_{3}$

Persamaan regresi dapat dijelaskan sebagai berikut:

$\mathrm{a}=0,884$ merupakan interpect yang berarti apabila variable bebas yang mempengaruhi $=0$, maka hasil yang diperoleh dari Disonansi Kognitif adalah sebesar 0,884 .

$\mathrm{b}_{1}=0,185$ Nilai pada variable

Emosional $\left(\mathrm{X}_{1}\right)$ bernilai positif 
artinya variable Emosional mempunyai pengaruh yang positif terhadap Disonansi Kognitif atau apabila Emosional meningkat satu satuan maka akan diikuti peningkatan Disonansi kognitif sebesar 0,185 satuan dengan asumsi variabel lain yang mempengaruhi dianggap konstant ( $\mathrm{a}, \mathrm{X}_{2}$ dan $\mathrm{X}_{3}=0$ )

$\mathrm{b}_{2}=$ Nilai 0,254 pada variable Kebijaksanaan pembelian $\left(\mathrm{X}_{2}\right)$ bernilai positif artinya variable Kebijaksanaan pembelian mempunyai pengaruh yang positif terhadap Disonansi kognitif atau apabila Kebijaksanaan pembelian meningkat satu satuan maka akan diikuti peningkatan Disonansi kognitif sebesar 0,254 satuan dengan asumsi variabel lain yang mempengaruhi dianggap konstant ( $a, X_{1}$ dan $X_{3}=0$ )

$b_{3}=$ Nilai 0,281 pada variable Perhatian setelah transaksi $\left(\mathrm{X}_{3}\right)$ bernilai positif artinya variable Perhatian setelah transaksi mempunyai pengaruh yang positif terhadap Disonansi Kognitif, atau apabila Perhatian setelah transaksi meningkat satu satuan maka akan diikuti peningkatan Disonansi Kognitif sebesar 0,281 satuan dengan asumsi variabel lain yang mempengaruhi dianggap konstant ( $\mathrm{a}, \mathrm{X}_{1}$ dan $\mathrm{X}_{2}=0$ )

3. Analisis Korelasi

Analisis korelasi dipahami sebagai tingkat keeratan antara masing masing variabel.
Tabel 3.

Hasil Korelasi

\begin{tabular}{|c|c|c|c|}
\hline No & Variabel & Korelasi & $\begin{array}{c}\text { Keteran } \\
\text { gan }\end{array}$ \\
\hline 1 & Emosional & 0,461 & Sedang \\
\hline 2 & $\begin{array}{c}\text { Kebijaksana } \\
\text { an } \\
\text { pembelian }\end{array}$ & 0,503 & Sedang \\
\hline 3 & $\begin{array}{c}\text { Perhatian } \\
\text { setelah } \\
\text { transaksi }\end{array}$ & 0,513 & Sedang \\
\hline
\end{tabular}

Sumber : Output SPSS 17

Dari tabel 3 diperoleh nilai korelasi $r$ tersebut mempunyai hubungan yang sedang terhadap Disonansi Kognitif Konsumen pada UD. Dika Jaya Motor Lamongan.

4. Koefisien Determinasi

Koefisien determinasi $\left(\mathrm{R}^{2}\right)$ untuk mengukur seberapa jauh kemampuan model dalam menerangkan variasi variabel pembentukan disonansi kognitif. Hasil koefisien determinasi pada Model Summary dapat diketahui bahwa besarnya nilai koefisien determinasi ditunjukkan oleh nilai $R$ Square yaitu sebesar 0,452 atau (45,2\%), sehingga dapat ditarik kesimpulan bahwa Emosional, Kebijaksanaan pembelian dan Perhatian setelah transaksi secara bersama - sama memberikan kontribusi sebesar 45,2\% Sedangkan sisanya sebesar 54,8\% dipengaruhi oleh variabel lain.

\section{Uji t}

Uji t pada dasarnya menunjukkan apakah variable bebas Emosional $\left(\mathrm{X}_{1}\right)$, Kebijaksanaan pembelian $\left(\mathrm{X}_{2}\right)$ dan Perhatian setelah transaksi $\left(\mathrm{X}_{3}\right)$ 
secara parsial / individu mempunyai pengaruh signifikan terhadap variable terikat Disonansi kognitif konsumen (Y) pada UD. Dika Jaya Motor Lamongan. Berdasarkan hasil uji $\mathrm{t}$ nilai signifikan $\alpha=0,05$, diperoleh nilai $\mathrm{t}_{\text {tabel }}$ sebesar $2,012 \mathrm{df}=\mathrm{n}-\mathrm{k}-1$ (50-3-1 = 46, $\left.t_{\text {tabel }} 2,012\right)$. Berikut adalah tabel yang menunjukkan hasil uji $t$ dan besarnya $t_{\text {tabel. }}$. Dengan analisa sebagai berikut:

1. Emosional $\left(\mathrm{X}_{1}\right)$

Dari hasil uji $\mathrm{t}$ diperoleh nilai $t_{\text {hitung (2.054) lebih besar dari }}$ $t_{\text {tabel }}(2,012)$ sehingga $t_{\text {hitung }}>$ $t_{\text {tabel }}$ dengan tingkat signifikansi $0,046<0,05$ maka $\mathrm{H}_{0}$ di tolak dan $\mathrm{H}_{1}$ diterima, yang artinya bahwa ada pengaruh yang signifikan secara parsial antara variable Emosional $\left(\mathrm{X}_{1}\right)$ terhadap Disonansi kognitif (Y) konsumen pemilik sepeda motor honda pada UD. Dika Jaya Motor Lamongan.

2. Kebijaksanaan pembelian $\left(\mathrm{X}_{2}\right)$

Dari hasil uji $\mathrm{t}$ diperoleh nilai $t_{\text {hitung (2.601) lebih besar }}$ dari $t_{\text {tabel }}(2,012)$ sehingga $t_{\text {hitung }}>$ $t_{\text {tabel }}$ dengan tingkat signifikansi $0,012<0,05$ maka $\mathrm{H}_{0}$ di tolak dan $\mathrm{H}_{1}$ diterima, yang artinya bahwa ada pengaruh yang signifikan secara parsial antara variable Kebijaksanaan Pembelian $\left(\mathrm{X}_{2}\right)$ terhadap Disonansi kognitif (Y) konsumen pemilik sepeda motor honda pada UD. Dika Jaya Motor Lamongan.

3. Perhatian setelah transaksi $\left(\mathrm{X}_{3}\right)$

Dari hasil uji $\mathrm{t}$ diperoleh nilai $t_{\text {hitung (3.051) lebih besar }}$ dari $t_{\text {tabel }}(2,012)$ sehinggat $t_{\text {hitung }}>$ $t_{\text {tabel }}$ dengan tingkat signifikansi $0,004<0,05$ maka $\mathrm{H}_{0}$ di tolak dan $\mathrm{H}_{1}$ diterima, yang artinya bahwa ada pengaruh yang signifikan secara parsial antara variable Perhatian setelah transaksi $\left(\mathrm{X}_{3}\right)$ terhadap Disonansi kognitif (Y) konsumen pemilik sepeda motor honda pada UD. Dika Jaya Motor Lamongan.

6. Uji F

Uji $F$ pada dasarnya menunjukkan apakah semua variable bebas yang dimasukkan kedalam model persamaan mempunyai pengaruh yang simultan terhadap variable terikat. Dari penelitian ini menunjukkan bahwa secara simultan variable Emosional $\left(\mathrm{X}_{1}\right)$, Kebijaksanaan pembelian $\left(\mathrm{X}_{2}\right)$ dan Perhatian setelah transaksi $\left(\mathrm{X}_{3}\right)$ berpengaruh signifikan terhadap Disonansi kognitif (Y) pada konsumen sepeda motor Honda pada UD. Dika Jaya Motor Lamongan.

Hasil uji F diperoleh Fhitung sebesar 12.650 sedangkan pada taraf nilai signifikansi $\alpha=0,05$ nilai $F_{\text {tabel }}$ df1=k-1 (3) dan df2 = n-k (50-4 = 46), jadi $F_{\text {tabel }} 2,81$ Hal ini dibuktikan dengan hasil Uji $F$ yang menunjukkan bahwa $F_{\text {hitung }}(12,650)>F_{\text {tabel }}(2,81)$. Dengan melihat hasil uji $\mathrm{F}$ ini, maka diperoleh asumsi bahwa $\mathrm{H}_{0}$ ditolak dan $\mathrm{H}_{1}$ diterima, sehingga teruji bahwa terdapat pengaruh yang signifikan antara variable Emosional $\left(\mathrm{X}_{1}\right)$, Kebijaksanaan pembelian $\left(\mathrm{X}_{2}\right)$ dan Perhatian setelah transaksi $\left(\mathrm{X}_{3}\right)$ terhadap pembentukan Disonansi Kognitif (Y) pemilik sepeda motor Honda pada UD. Dika Jaya Motor Lamongan. 
KESIMPULAN DAN SARAN

\section{Kesimpulan}

Berdasarkan pembahasan diatas dapat dikatakan bahwa Secara parsial dari hasil uji $\mathrm{t}$ diperoleh variabel bebas Emosional berpengaruh secara signifikan terhadap Disonansi Kognitif. Kebijaksanaan pembelian berpengaruh secara signifikan terhadap Disonansi Kognitif dan Perhatian setelah transaksi berpengaruh secara signifikan terhadap Disonansi variabel Emosional, kebijaksanaan pembelian dan perhatian setelah transaksi berpengaruh secara signifikan terhadap pembentukan disonansi kognitif.

Dari hasil uji F yang menunjukkan bahwa variabel Emosional, Kebijaksanaan pembelian dan Perhatian setelah transaksi berpengaruh signifikan terhadap Pembentukan Disonansi Kognitif Konsumen pemilik sepeda motor Honda pada UD. Dika Jaya Motor Lamongan.

Variabel bebas yang paling dominan dalam mempengarui Pembentukan Disonansi Kognitif pada UD. Dika Jaya Motor Lamongan adalah Perhatian setelah transaksi.

\section{Saran}

Hal ini menunjukkan bahwa kinerja pelayanan UD. Dika jaya Motor Lamongan serta produk Honda baik.

Terus dipertahankan dan bahkan lebih ditingkatkan lagi dengan cara selalu memberikan pelayanan dan produk yang terbaik bagi para konsumennya secara menyeluruh. Semoga hasil penelitian dapat dijadikan masukan serta pertimbangan bagi perusahaan dalam proses pengembangan pelayanan serta produknya.

Dengan diketahuinya perhatian setelah transaksi merupakan faktor yang paling dominan terhadap pembentukan disonansi kognitif konsumen pada UD. Dika Jaya Motor Lamongan, maka berdasarkan hasil tersebut hendaknya pihak perusahaan benar-benar mengetahui harga dan kualitas yang di tetapkan pesaing sehingga relatif tidak mahal.

\section{DAFTAR PUSTAKA}

Arikunto, Suharsimi. 2010. Prosedur Penelitian Suatu Pendekatan Praktik, Cetakan Keempat Belas, PT Rineka Cipta Jakarta.

Japarianto, Edwin. 2006. Analisis Pembentukan Disonansi Kognitif Konsumen Pemilik mobil Toyota Avanza. Skripsi, FE Universitas Kristen Petra Surabaya.

Morissan. 2010. Periklanan Komunikasi Pemasaran Terpadu, Edisi Pertama, Penerbit Kencana Jakarta.Prasetijo, Ristiyanti. 2005. Perilaku Konsumen, Edisi Pertama, Penerbit CV.Andi Offset Yogyakarta.

Narbuko, Cholid dan H.Abu Achmadi. 2010. Metodologi Penelitian, Cetakan Kesebelas, Penerbit PT.Bumi Askara Jakarta. 
Prasetijo, Ristiyanti. 2005. Perilaku

Konsumen, Edisi Pertama,

Penerbit CV.Andi Offset

Yogyakarta.

Sugiyono .2014. Statistika Untuk

Penelitian, Penerbit CV.

ALFA BETA Bandung

Supriyanto dan Ernawati. 2010.

Pemasaran Industri Jasa

Kesehatan, Edisi Pertama,

Penerbit CV.Andi Offset

Yogyakart 